\title{
Prevalence of syphilis and hepatitis B among homosexual men in two saunas in Amsterdam
}

\author{
ANS BLEEKER, R A COUTINHO, JEANETTE BAKKER-KOK, D TIO, \\ AND G A J DE KONING \\ From the Department of Infectious Diseases, Municipal Health Service, Amsterdam, the Netherlands
}

SUMMARY In a pilot study by field-screening in two different sauna baths, a day-sauna and a night-sauna, 318 homosexual men were investigated for syphilis and hepatitis $B$ surface antigen (HBsAg) and its antibody (anti-HBs). Of the 134 visitors to the day-sauna $35 \cdot 1 \%$ were seroreactive for syphilis, four $(3 \%)$ carried $\mathrm{HBsAg}$, and $95(70.9 \%)$ anti-HBs. Of the 184 visitors to the night-sauna $33 \cdot 2 \%$ were seroreactive for syphilis, $16(8 \cdot 7 \%)$, carried $\mathrm{HBsAg}$, and $97(52 \cdot 7 \%)$ anti-HBs. The correlation between seroreactivity for syphilis and the presence of $\mathrm{HBsAg}$ and antiHBs was statistically significant.

\section{Introduction}

The number of reported cases of infectious syphilis in Amsterdam has more than doubled in the last three years, from 335 in 1976 to 703 in 1979. As it was not clear among which sections of the population the disease was spreading, we decided to study the epidemiology more thoroughly.

Evidence from our clinics for sexually transmitted diseases (STDs) and from published reports ${ }^{1-3}$ indicated that syphilis' occurred frequently in sexually-active homosexual men. A pilot study was set up among male homosexuals visiting two sauna baths in Amsterdam, which were accessible only to men. As it is known that hepatitis B has a high prevalence in this group, ${ }^{4-10}$ sera were also tested for hepatitis B markers. The results of this pilot study are presented.

\section{Subjects and methods}

\section{STUDY POPULATION}

The study population consisted of homosexual men visiting a day-sauna and a night-sauna, which were accessible only to men. These saunas are in the centre of Amsterdam; the men meet each other and frequently have sexual intercourse. One of us (JB-K) was present and informed the visitors of the nature of the study and invited them to participate. More than half the men agreed to take part and were questioned

Address for reprints: Dr R A Coutinho, Municipal Health Service, P O Box 20244, 1000 HE Amsterdam, the Netherlands

Accepted for publication 10 November 1980 about their age, place of residence, and history of syphilis and hepatitis. An important reason why $\overrightarrow{0}$ some men did not participate was because they were $\propto$ undergoing regular blood tests for syphilis at an STD : clinic or with a general practitioner. None of the participants gave a history of drug abuse. They were assured of the confidentiality of all personal information given.

During one week in August 1979 blood samples were collected from the participants by venepuncture. The men were informed of the results and, if necessary, advised to visit their general practitioner or an STD clinic.

\section{SEROLOGICAL TESTS FOR SYPHILIS}

Sera were inactivated at $56^{\circ} \mathrm{C}$ for 30 minutes before testing. The qualitative serological screening tests comprised the Venereal Disease Research Laboratory (VDRL) slide test (Wellcome) and the Reiter protein complement-fixation (RPCF) test. The Kolmer complement-fixation test and the Treponema pallidum haemagglutination assay (TPHA, Fujizoki) were performed quantitatively.

Sera which were reactive in one or more of the four screening tests were confirmed by the fluorescent $N$ treponemal antibody-absorption (FTA-ABS) and the $T$ pallidum immobilisation (TPI) tests. Both tests were performed at the National Institute of Public Health (Bilthoven, the Netherlands).

The diagnosis and determination of the stage of : syphilis require integration of historical data, physical findings, and darkfield examination and serological test results. Since only the results of serological tests were available no distinction could be made between treated and untreated syphilis. 
The diagnoses were determined by the following criteria:

(a) Non-syphilitic: all four serological screening tests results were negative;

(b) Possible biological false-positive results: reactive VDRL or RPCF test results or both and non-reactive FTA-ABS and TPI test results;

(c) Old syphilis: reactive TPHA test results (with or without other reactive treponemal tests) and non-reactive non-treponemal test results;

(d) Recent syphilis: one or two non-treponemal and one or more treponemal tests with reactive results.

\section{SEROLOGICAL TESTS FOR HEPATITIS B}

Each serum sample was screened for hepatitis B surface antigen (HBsAg) by reverse passive haemagglutination (Auscell, Abbott Laboratories). Positive results were confirmed by radioimmunoassay (Ausria, Abbott Laboratories). HBsAgnegative sera were tested for the presence of hepatitis B surface antibody (anti-HBs) both by radioimmunoassay (Ausab, Abbott Laboratories) and passive haemagglutination. All these tests were performed at the Central Laboratory of the Red Cross Blood Transfusion Service (Amsterdam, the Netherlands).

STATISTICAL ANALYSIS

Data were analysed statistically by the $\chi^{2}$ test.

\section{Results}

\section{DISTRIBUTION ACCORDING TO AGE AND} PLACE OF RESIDENCE

A total of 318 men participated in the study, 134 attending the day-sauna and 184 the night-sauna.
The mean age of the former group was $36 \cdot 2$ years (range 20-70 years) and of the latter 31 years (range 18-54 years). The peak age distribution was 30-34 years in both groups. Of the $\mathbf{3 1 8}$ men studied, 146 lived in Amsterdam, 125 elsewhere in the Netherlands, 44 were foreigners, and the place of residence of three was unknown. The distribution of places of residence was similar in both groups.

\section{PREVALENCE OF SYPHILIS}

Fifty-four $(\mathbf{4 0} \cdot 3 \%)$ sera from the day-sauna group and $68(37 \%)$ from the night-sauna group were reactive in one or more of the four screening tests. In both groups seven sera were classified as giving biological false-positive results. From the day-sauna and the night-sauna groups $35(26 \cdot 1 \%)$ and 20 $(10 \cdot 8 \%)$ sera respectively were classified as old syphilis and $12(9 \%)$ and $41(22 \cdot 3 \%)$ sera respectively as recent syphilis.

A history of syphilis was given by 33 of the 54 men attending the day-sauna and by 38 of the 68 attending the night-sauna (table I).

Recent or old syphilis was diagnosed in 51 of 146 visitors to the saunas who lived in Amsterdam, in $\mathbf{4 6}$ of 125 who lived elsewhere in the Netherlands, and in 10 of 44 who came from other countries.

PREVALENCE OF HBsAg AND ANTI-HBs

The distribution by age of HBsAg and anti-HBs for the men in both saunas is shown in table II. Hepatitis B markers were found in $\mathbf{9 9}(\mathbf{7 3 \%})$ of the visitors to the day-sauna and in $113(61 \cdot 4 \%)$ of the visitors to the night-sauna.

The distribution of $\mathrm{HBsAg}$ and anti-HBs according to residence is shown in table III.

TABLE I Results of Kolmer complement-fixation, VDRL, Reiter protein complement-fixation (RPCF), TPHA, FTA-ABS, and TPI tests performed on 134 and 184 sera from men visiting a day-sauna and a night-sauna respectively. The number in brackets indicates men who gave histories of treated syphilis (stage not stated).

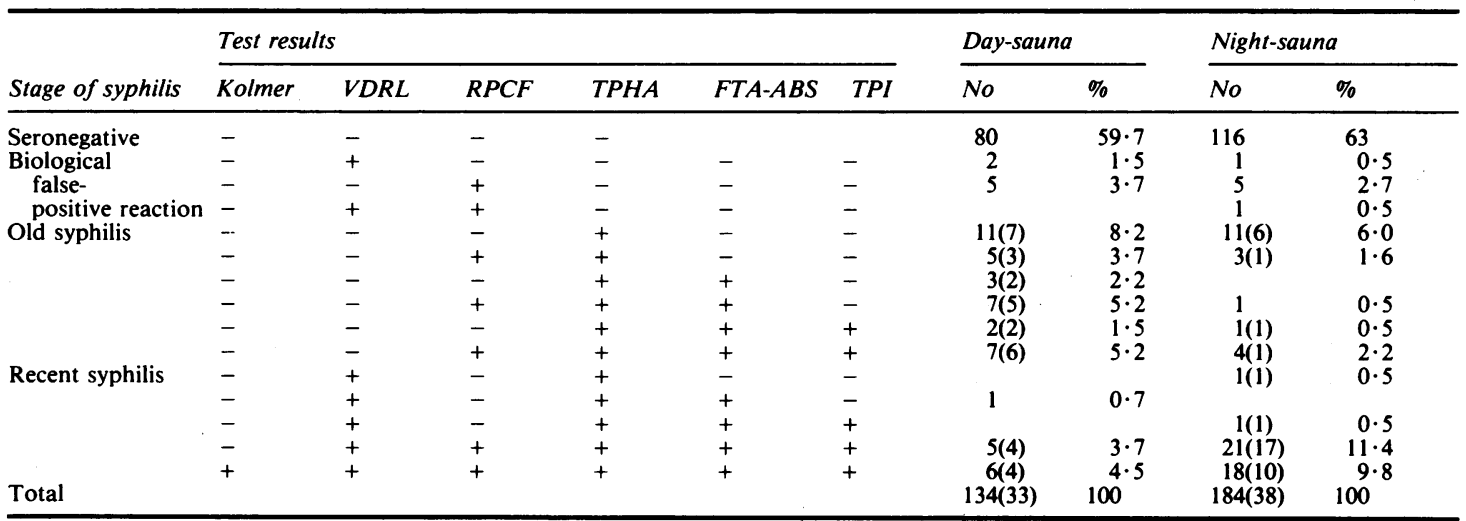

+ Reactive - non-reactive 
TABLE II Distribution according to age of HBsAg and anti-HBs among the 134 visitors to the day-sauna and 184 visitors to $\stackrel{\mathbb{Q}}{\vec{C}}$ the night-sauna. The number of visitors who gave a history of hepatitis is shown in brackets.

\begin{tabular}{|c|c|c|c|c|c|c|}
\hline \multirow[b]{2}{*}{ Age } & \multicolumn{3}{|c|}{ Day-sauna } & \multicolumn{3}{|c|}{ Night-sauna } \\
\hline & No & $\begin{array}{l}\text { HBsAg- } \\
\text { positive }\end{array}$ & $\begin{array}{l}\text { Anti-HBs- } \\
\text { positive }\end{array}$ & No & $\begin{array}{l}\text { HBsAg- } \\
\text { positive }\end{array}$ & $\begin{array}{l}\text { Anti-HBs- } \\
\text { positive }\end{array}$ \\
\hline$<20$ & & & & 7 & 1 & $4(1)$ \\
\hline $20-24$ & 9 & & $8(2)$ & 30 & 2 & $9(1)$ \\
\hline $25-29$ & 26 & 1 & $13(2)$ & 36 & 3 & $17(3)$ \\
\hline $30-34$ & 35 & $1(1)$ & $28(3)$ & 45 & $6(3)$ & $24(7)$ \\
\hline $35-39$ & 23 & 1 & $16(3)$ & 37 & $2(2)$ & $26(7)$ \\
\hline $40-44$ & 13 & & $9(3)$ & 14 & & $9(3)$ \\
\hline $45-49$ & 13 & 1 & $10(3)$ & 7 & $1(1)$ & $4(1)$ \\
\hline $50-54$ & 7 & & $3(1)$ & 6 & $1(1)$ & $3(2)$ \\
\hline $55-59$ & 3 & & $3(1)$ & & & \\
\hline $60-64$ & 2 & & 2 & & & \\
\hline $65-69$ & 1 & & 1 (1) & & & \\
\hline $70-74$ & 1 & & $1(1)$ & & & \\
\hline Age unknown & 1 & & $1(1)$ & 2 & & 1 \\
\hline Total & 134 & $4(1)$ & $95(21)$ & 184 & $16(7)$ & $97(25)$ \\
\hline
\end{tabular}

TABLE III Distribution by place of residence of presence of $\mathrm{HBs} A \mathrm{~g}$ and anti-HBs in visitors to the two saunas.

\begin{tabular}{|c|c|c|c|c|c|c|c|c|}
\hline \multirow[t]{2}{*}{ Residence } & \multicolumn{2}{|c|}{ Total } & \multicolumn{2}{|c|}{ HBsAg-positive } & \multicolumn{2}{|c|}{ Anti-HBs-positive } & \multicolumn{2}{|c|}{$\begin{array}{l}\text { HBsAg-and Anti- } \\
\text { HBs-negative }\end{array}$} \\
\hline & No & $\%$ & No & $\%$ & No & $\%$ & No & $\%$ \\
\hline \multicolumn{9}{|l|}{ Day-sauna } \\
\hline Amsterdam & 54 & $40 \cdot 3$ & 4 & $3 \cdot 0$ & 38 & $28 \cdot 4$ & 12 & $9 \cdot 0$ \\
\hline The Netherlands & 65 & $48 \cdot 5$ & & & 47 & $35 \cdot 1$ & 18 & $13 \cdot 4$ \\
\hline Other countries & 13 & $9 \cdot 7$ & & & 9 & $6 \cdot 7$ & 4 & $3 \cdot 0$ \\
\hline Residence unknown & 2 & $1 \cdot 5$ & & & 1 & 0.7 & 1 & 0.7 \\
\hline Total & 134 & $100 \cdot 0$ & 4 & $3 \cdot 0$ & 95 & $70 \cdot 9$ & 35 & $26 \cdot 1$ \\
\hline \multicolumn{9}{|l|}{ Night-sauna } \\
\hline Amsterdam & 93 & $50 \cdot 6$ & 7 & $3 \cdot 8$ & 50 & $27 \cdot 2$ & 36 & $19 \cdot 6$ \\
\hline The Netherlands & 60 & $32 \cdot 6$ & 8 & $4 \cdot 3$ & 34 & $18 \cdot 5$ & 18 & $9 \cdot 8$ \\
\hline Other countries & 30 & $16 \cdot 3$ & 1 & 0.5 & 13 & $7 \cdot 1$ & 16 & $8 \cdot 7$ \\
\hline Residence unknown & 1 & 0.5 & & & & & 1 & 0.5 \\
\hline Total & 184 & $100 \cdot 0$ & 16 & $8 \cdot 7$ & 97 & $52 \cdot 7$ & 71 & $38 \cdot 6$ \\
\hline
\end{tabular}

\section{Discussion}

The sera of $122(38 \cdot 4 \%)$ of the 318 male homosexuals gave positive results in one or more of the four serological screening tests for syphilis. However, three sera gave positive results in the VDRL slide test alone, 10 in the RPCF test alone, and one in both tests. None of these 14 sera was from men with a history of syphilis. On the basis of non-reactive TPI and FTA-ABS test results and the absence of a history of syphilis, we assumed that these 14 sera were biological false-positive reactions.

The TPHA was the only test giving a positive result in 22 of the 318 sera; 13 of these were from men who gave a history of previous syphilis. The TPHA has been evaluated by many workers. The results obtained suggest that this test is highly specific and sensitive for the detection of treated and untreated syphilis. ${ }^{11-13}$ We therefore assumed that the 22 sera with isolated positive TPHA results were not due to biological false-positive reactions. Thus, $108(34 \%)$ sera from the 318 visitors to the saunas were con sidered to be seroreactive for syphilis. These results indicate that sexually active homosexual men are at high risk of acquiring syphilis. Similar conclusions were given by Fluker ${ }^{1}$ and the British Co-operative Clinical Group. ${ }^{3}$

The prevalence of syphilis among the visitors to the $\frac{7}{O}$ saunas was not related to their place of residence.

In the group with recent syphilis six sera from men N in the day-sauna and 18 from men in the night-sauna $N$ gave positive results in all six serological tests. The Kolmer complement-fixation test titre was $1 / 80$ or $\omega$ higher in nine of these 24 sera. None of these nine patients gave a history of syphilis; they were thought to have recent untreated syphilis.

This pilot study suggests that field-screening of $\stackrel{+}{\cdot}$ specific groups is an effective means of detecting new $\frac{0}{3}$ cases of syphilis. Regular serological screening for $\overrightarrow{\mathbb{D}}$

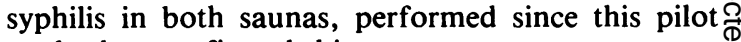
study, has confirmed this.

Sera from $20(6 \cdot 3 \%)$ visitors gave positive results? 
for HBsAg. This is very high when compared with $0 \cdot 224 \%$ HBsAg-positivity among new Dutch blood donors. ${ }^{14} \mathrm{~A}$ further 192 sera contained anti-HBs. Thus, $66 \cdot 7 \%$ of the 318 visitors to the saunas were hepatitis-B-marker-positive. If we had also tested the sera for antibodies against hepatitis B core antigen (anti-HBc), this percentage would have been even higher..$^{15}$ Our results correspond with the findings of others $^{9}{ }^{15}$ and indicate that active male homosexuals are at high risk of contracting hepatitis B.

Comparison of the prevalence of syphilis and hepatitis $B$ in the 318 male homosexual visitors showed a significant correlation $(\mathrm{P}<0.001)$ between seroreactivity for syphilis and hepatitis-B-marker positivity (table IV).

TABLE IV Prevalence of syphilis and hepatitis $B(H B s$ Ag and anti-HBs) among 318 homosexual visitors to saunas.

\begin{tabular}{llll}
\hline & \multicolumn{2}{l}{ Hepatitis $B$} & \\
\cline { 2 - 4 } Syphilis & Marker-positive & Marker-negative & Total \\
\hline Reactive & 92 & 16 & 108 \\
Non-reactive & 120 & 90 & 210 \\
Total & 212 & 106 & 318 \\
\hline
\end{tabular}

These results substantiate the observations of others $^{4-6} 16$ that hepatitis B among promiscuous male homosexuals is, like syphilis, a sexually transmitted disease.

We thank Dr B Lafebar-Schut and the staff of the Central Laboratory of the Red Cross Blood Transfusion Service (Amsterdam, the Netherlands); Dr H E Menke and the staff of the National Institute of Public Health (Bilthoven, the Netherlands); Mrs F A P Randshuizen and Mr A B R Ran of the bacteriological laboratory of the Municipal Health Service (Amsterdam, the Netherlands) for their technical assistance; and Mrs W M Maruanaya for typing the manuscript.

\section{References}

1. Fluker JL. A 10-year study of homosexually transmitted infection. Br J Vener Dis 1976; 52: 155-60.

2. Thin RN, Smith DM. Some characteristics of homosexual men. Br J Vener Dis 1976;52: 161-4.

3. British Co-operative Clinical Group. Homosexuality and venereal disease in the United Kingdom. Br J Vener Dis 1980;56:6-11.

4. Vahrman J. Transmission of hepatitis. Lancet 1970; i: 774.

5. Fulford KWM, Dane DS, Catterall RD, Woof R, Denning JV. Australia antigen and antibody among patients attending a clinic for sexually transmitted diseases. Lancet $1973 ; \mathrm{i}: 1470-3$.

6. Heathcote J, Sherlock S. Spread of acute type-B hepatitis in London. Lancet 1973; ii: 1468-70

7. Jeffries DJ, James WH, Jefferiss FJG, MacLeod KG, Willcox RR. Australia (hepatitis-associated) antigen in patients attending a venereal disease clinic. Br Med J 1973;ii:455-6.

8. Coleman JC, Waugh M, Dayton R. Hepatitis B antigen and antibody in a male homosexual population. Br J Vener Dis 1977;53:132-4.

9. Zuckerman AJ. Sexual transmission of hepatitis B.Nature 1977; 266: 14-5.

10. Inaba N, Ohkawa R, Matusuura A, Kudoh J, Takamizawa $H$. Sexual transmission of hepatitis B surface antigen. Br J Vener Dis 1979; 55: 366-8.

11. Garner MF, Backhouse JL, Daskalopoulos W, Walsh JL. Treponema pallidum haemagglutination test for syphilis: comparison with the TPI and FTA-ABS tests. Br J Vener Dis 1972; 48:470-2.

12. Young $\mathrm{H}$, Henricksen $\mathrm{C}$, Robertson DHH. Treponema pallidum haemagglutination test as a screening procedure for the diagnosis of syphilis. Br J Vener Dis 1974;50:341-6.

13. Luger A, Schmidt B, Spendlingwimmer I, Horn F. Recent observations on the serology of syphilis. $\mathrm{Br} J$ Vener Dis 1980; 56: $12-6$.

14. Reesink HW. Studies on transmission and prevention of hepatitis B. PhD Thesis, University of Amsterdam, 1980.

15. Coleman JC, Evans BA, Thornton A, Zuckerman AJ. Homosexual hepatitis. J Infection 1979; 1:61-6.

16. Vranck R. Hepatitis $B$ antigen and serological evidence of syphilis. Lancet 1975; i: 1193. 